\title{
Entre rieles y asfalto. Bogotá, transporte y vida urbana: $1938-1954^{1}$
}

\section{Leopoldo Prieto Páez ${ }^{2}$}

Universidad Nacional de Colombia, Colombia

lprietop@unal.edu.co

Recibido: 15 de febrero de 2017

Aceptado: 6 de agosto de 2017

Disponible en línea: 30 de junio de 2018

1 Artículo de revisión cuya investigación no contó con financiación institucional.

2 Sociólogo. Magister en Urbanismo. Estudiante y candidato a Doctor en Arte y Arquitectura, Universidad Nacional de Colombia (Colombia). 


\title{
Entre rieles y asfalto. Bogotá, transporte y vida urbana: 1938-1954
}

\section{Resumen}

A mediados del siglo XX Bogotá se encontraba inmersa en un proceso de transformación profundo y complejo, agenciado por dos factores fundamentales: el crecimiento demográfico desbordado y la extensión de la urbanización mucho más allá de los límites urbanos permitidos. Un componente fundamental que acompañó este proceso fue la transformación de las formas y medios de locomoción de los habitantes de la ciudad, determinado por el incremento de vehículos, la transformación del modelo de transporte público y la búsqueda de alternativas ante las consecuencias que produjeron los dos aspectos mencionados. El objetivo de este artículo es entender cuál fue el costo social que debió asumir en términos de movilidad la capital colombiana para convertirse en una urbe "moderna". La expectativa radica, por tanto, en que a partir del análisis de los diferentes aspectos mencionados sobre movilidad de la ciudad, se pueda entender la difícil negociación entre cambios urbanísticos y formas de habitar la ciudad.

Palabras clave: transporte urbano; Bogotá-transporte público; accidentalidad urbana

\section{Between rails and asphalt. Bogotá, transportation and urban life: 1938-1954}

\begin{abstract}
In the middle of the 20th century, Bogota was immersed in a profound and complex process of transformation driven by two fundamental factors: unchecked population growth and the extension of urbanization well beyond the permitted urban limits. A fundamental component that accompanied this process was the transformation of the means of locomotion of the inhabitants of the city, as determined by the increase of vehicles, the transformation of the public transportation model, and the search for alternatives to the consequences produced by the two aforementioned aspects. The objective of this article is to understand what kind of social cost the Colombian capital had to take on, in terms of mobility, to become a "modern" city. The expectation is, therefore, that based on the analysis of the different aspects mentioned about mobility of the city, one can understand the difficult negotiation between urban changes and ways of inhabiting the city.
\end{abstract}

Keywords: urban transport; Bogotá-public transportation; urban accident rates

\section{Entre trilhos e asfalto. Bogotá, transporte e vida urbana: 1938-1954}

\section{Resumo}

Em meados do século XX, Bogotá encontrava-se imersa em um processo de transformação profundo e complexo, agenciado por dois fatores fundamentais: o acréscimo demográfico superlotado e a extensão da urbanização muito para além dos limites urbanos permitidos. Um componente fundamental que acompanhou esse processo foi a transformação das formas e meios de locomoção dos moradores da cidade, determinado pelo incremento de veículos, a transformação do modelo de transporte público e a procura de alternativas perante as consequências produzidas pelos dois aspectos mencionados. O objetivo deste artigo é compreender qual o custo social que a capital colombiana deveu assumir em termos de mobilidade para se tornar uma urbe "moderna". A expetativa radica, por tanto, em puder entender a difícil negociação entre mudanças urbanísticas e formas de habitar a cidade a partir da análise dos diferentes aspectos mencionados sobre mobilidade da cidade.

Palavras-chave: transporte urbano; Bogotá-transporte público; acidentalidade urbana 
Nosotros afirmamos que la magnificencia del mundo se ha enriquecido con una nueva belleza:

la belleza de la velocidad. Tommaso Marinetti, Manifiesto del Futurismo

\section{Introducción}

A finales de la década de 1930, luego de los primeros impulsos modernizadores de la llamada República Liberal, era claro para muchos bogotanos que el ritmo de las transformaciones urbanas se había acelerado; en parte por las políticas gubernamentales, en parte como resultado del empuje económico, y en parte también por el aumento demográfico. Las obras realizadas para la celebración del cuarto Centenario de la fundación de la ciudad, la contratación del Karl Brunner en el departamento de Urbanismo, el avance en la cobertura de servicios públicos como agua y electricidad, así como el florecimiento de nuevas zonas urbanas en terrenos donde previamente había haciendas y pastos agrícolas constituían señales claras de una vorágine de nuevos tiempos.

Un indicador importante del alcance de estas transformaciones fue el paulatino impacto en el sistema de transporte y de movilidad de los ciudadanos. Cada vez eran más los autos privados que rodaban por las calles de la ciudad; mientras que en 1940 había 4000, trece años después la cifra se elevó a 18000 (Anuario Municipal de Estadística). La extensión del tranvía municipal había aumentado de 16 kilómetros en 1913 a 59 kilómetros en 1940 (Jaramillo y Parias, 1995), pero incluso así resultaba insuficiente para atender la demanda creada por las urbanizaciones surgidas en los limites municipales y aun por fuera de ellos. A tenor de esto, se multiplicaron las empresas que prestaban el servicio de transporte, y en improvisados camiones adaptados con el afán que exigía el negocio se inauguraba el modelo de transporte masivo urbano que imperaría en la ciudad por más de medio siglo. 
Este movimiento implicó por otra parte la adecuación arquitectónica y urbanística de los espacios al nuevo eje fundamental de la movilidad de los bogotanos. Efemérides como la ya mencionada conmemoración del cuarto Centenario de fundación de la ciudad en 1938 o la realización de la Novena Conferencia Panamericana en 1948, eran el patrón de medida de este objetivo. La apertura y ensanchamiento de avenidas, la adecuación de viejas calles y la construcción de modernas vías parecía ser la obsesión de gobernantes y pensadores de la ciudad, que encontraban en el auto el símbolo más contundente del modo de vida de los tiempos modernos.

Como en cualquier ciudad en proceso de modernización, el transporte público y las formas de movilidad se convirtieron en uno de los indicadores más infalibles a través del cual se percibía no solo el crecimiento de la ciudad, sino también la irrupción de un modo de vida urbano. Los sociólogos de la Escuela de Chicago aseguraban, por ejemplo, que "la movilidad de una población es incuestionablemente un factor muy importante en su desarrollo intelectual" (Park, 1925, s.p.); ${ }^{3}$ según el mismo Robert Park porque "fomentan las oportunidades de contacto y asociación con otros, pero de manera más transitoria e inestable" (1925, s.p.); uno de los elementos que George Simmel (1986) define como central en la configuración del modo de vida típico de la gran urbe. La movilidad urbana y la necesaria implementación de sistemas o mecanismos más complejos de locomoción sugería que había lugares ahora inalcanzables para peatones y, por tanto, el espacio urbano experimentaba "una redistribución de las funciones que antes se concentraban en la vida cotidiana barrial", más aún, el mundo de la vida de los habitantes bogotanos se reorganiza multiespacialmente, "a partir de intersecciones o nodos, en lo que Moulet señala como el paso de

3 Tanto Park como Burgess y varios de los sociólogos de la Escuela de Sociología Urbana de Chicago reconocían la importancia que tenía el movimiento en los ambientes urbanos modernos. Wirth, por ejemplo, aseguraba que "el ser humano tiene una característica singular derivada de que los hombres en gran medida construyen su propio ambiente, tienen gran poder de locomoción y están por lo tanto menos atados al hábitat inmediato, en el cual son puestos" (Citado por Lezama, 2005, p. 195). El movimiento constante era quizá uno de los ejes fundamentales en el marco de comprensión de los organismos en un ambiente urbano. Vale la pena anotar que, a pesar de lo valioso de este elemento, el modelo de la escuela ecologista clásica de Chicago se ve limitado por lo que el mismo Lezama señala como excesos cometidos con el símil biológico "y la fuerte carga empirista que los lleva a universalizar sus hallazgos, lo que los hace quedar en muchos casos, atrapados por la presencia arrasadora de un objeto empírico" (2005, p. 184). 
una vida cotidiana afincada en lo local hacía lo nodal [...] La ciudad se reorganiza para favorecer estos encuentros" (Vega, 2003, p. 30). Entender cómo ocurrieron estos encuentros en el marco de una ciudad masificada es uno de los objetivos de este trabajo.

Así mismo, la presencia del bus urbano y la constatación de una incipiente pero paulatina popularización del automóvil privado, hacían evidente que los valores construidos alrededor del transporte motorizado en el mundo industrializado tenían eco en la capital colombiana. Era posible constatar en la Bogotá de los años 40 y 50 varios de los elementos que constituyen el concepto de automobility, una noción formulada por Urry (2015) que explica los cambios en la movilidad urbana en el siglo XX, no solo en las metrópolis, sino casi que en cada rincón del planeta. Esos aspectos eran la presencia de la industria automotriz mundial en la ciudad, la construcción de una imagen de estatus individual definida por la posesión del auto y de modernidad colectiva definida por la presencia de buses; el vínculo de una enorme red de actividades productivas dependientes de los automotores, la subordinación de otro tipo de movilidades a un modelo motorizado y el consumo ingente de recursos ambientales.

Teniendo en cuenta lo anterior, el objetivo de este artículo se centra justamente en tratar de entender cómo los cambios en la movilidad urbana de medio siglo, en cierto modo articulados con ideas globales sobre el transporte motorizado, impactaron y configuraron las formas de comportamiento de los habitantes de la ciudad: ¿qué tuvo que adaptarse?, ¿qué iniciativas fracasaron?, ¿de qué manera los ideales e imágenes construidos sobre la movilidad en una ciudad moderna se enfrentaron a viejas costumbres de los habitantes de la ciudad? En definitiva, ¿cómo se redefine la idea del espacio público en función de los nuevos modos de locomoción y de movilidad?

El periodo de análisis de este trabajo está definido por los años que corren entre la celebración del cuarto Centenario de la fundación de la ciudad -1938-y la creación del Distrito Especial de Bogotá en 1954, que implicó la ampliación de los límites de la misma y la 
anexión de seis municipios vecinos. La pertinencia de este periodo, más allá del incremento acelerado de automóviles, buses, bicicletas, camiones y otro tipo de vehículos de locomoción, radica en que, tal como lo han señalado algunos estudiosos de la ciudad, "en 1945 el problema del transporte en Bogotá era el segundo en gravedad después de la escasez de agua" (Zambrano, 2007, p. 127), y si se mide por la cantidad de campañas educativas, acciones de política pública, crónicas ciudadanas y el espacio que ocupa en la agenda pública de los medios de comunicación, la afirmación ciertamente no carece de sustento. De hecho, se percibe que tal preocupación se extendió por toda la década y ya no dejaría de estar presente como un problema central de la vida de la ciudad.

Quizá debido al crecimiento de la ciudad y al modo como los problemas de servicios públicos y de gestión municipal afectaban la vida de los ciudadanos, cada vez más los asuntos urbanos ocupaban un papel preponderante en las discusiones públicas consignadas en la prensa local y nacional. Los debates, ideas y proyectos encontraban una caja de resonancia en los medios de comunicación, en donde, como nunca antes, expertos e interesados emitían juicios sobre las condiciones del desarrollo urbanístico de la ciudad. Ejemplo de ello eran las constantes crónicas urbanas, los reportajes gráficos, las páginas semanales sobre urbanismo y construcciones, así como la aparición de publicaciones especializadas. Tal fue el caso de la revista Proa, que, a diferencia de sus predecesoras, superó el efimero entusiasmo de los primeros números y pudo mantener la frecuencia durante varias décadas.

El interés en este tipo de fuentes dentro de este texto radica en al menos dos aspectos: en primer lugar, porque permite dilucidar las contradicciones y el amplio abanico de visiones que la élite política tenía sobre el futuro inmediato de Bogotá. En segunda instancia, porque es claro el interés creciente de periodistas y reporteros en un asunto no muy tratado en la prensa hasta entonces: la cotidianidad de los habitantes de la ciudad. Ambos elementos ofrecen al historiador algunas pistas sobre la manera como ciudadanía y administradores urbanos enfrentaron las rápidas transformaciones, 
y deja en evidencia una disonancia entre las expectativas de cada grupo en relación a la vida urbana.

Los asuntos considerados aquí como fundamentales de la movilidad y el transporte bogotano a mediados del siglo XX han sido divididos en tres apartados. En primer lugar, se busca entender qué papel tuvo la construcción de una imagen simbólica de la movilidad en una ciudad moderna. En segundo lugar, se aborda el tema del transporte público y en particular la controversia surgida a propósito del remplazo del tranvía por otro modelo de transporte masivo sustentado en buses urbanos. Finalmente, se busca entender algunas consecuencias en la vida urbana originadas por estos cambios.

\section{La modernidad sobre ruedas}

Desde mediados de la década del treinta y hasta 1952 se proponen para Bogotá al menos cuatro planes viales: el Plan Vial de Karl Brunner en 1936, el plan vial de la Sociedad Colombiana de Arquitectos en 1944, el plan vial de la revista Proa en 1946 y el Plan Vial de Le Corbusier en 1951 (Saldarriaga, 2000, pp. 102-103). En cada uno de estos casos se cumplía la máxima de Leonardo Benevolo sobre el urbanismo moderno, "la técnica urbanística se encuentra, en general, retrasada respecto a los acontecimientos que debería controlar, y conserva el carácter de un remedio aplicado a posteriori" (Benevolo, 1992, p. 7). En efecto, en 1946 la revista Cromos publicó una crónica titulada "La circulación el Gran Problema de Bogotá”, en cuyo texto se hacían las siguientes consideraciones:

Con rigurosas excepciones nuestras calles y carreras tienen un ancho que no pasa de seis metros, siete a lo sumo. ¿cómo es posible [...] que por una calzada de tales dimensiones se pretenda hacer circular, como por ejemplo, en la carrera 6 entre calles 2 y 9 , vehículos en ambas direcciones y además de esto estacionarlos con carácter indefinido? ("La circulación...", 1946, p. 2) 
A la queja, el articulista le sumaba la observación de una inaplazable adecuación de las vías bogotanas, que consideraba poco dignas de una ciudad capital y estremecedoramente incómodas para el tráfico de esos años. Por la misma época, el principal medio de comunicación de arquitectos y urbanistas, la revista Proa, lanza una diatriba en términos similares a los del periodista. Afirman allí que:

Todo el problema actual reside en el hecho de que Bogotá tiene demasiadas calles incapacitadas para las actuales y futuras exigencias del movimiento de vehículos. La ciudad tiene muy pocas calles anchas. Con calles anchas se llega pronto al lugar de trabajo. La calle ancha es valorización. [...] Bogotá necesita de cirugia; de cirugía siglo XX y en gran escala. ("Las futuras grandes...", 1946, p. 20)

Este tipo de demandas, que paulatinamente se hacian más comunes en la prensa, estaban en la mente de políticos y administradores de la ciudad. El primer periodo de la alcaldía de Fernando Mazuera en 1947 -y ciertamente los otros periodos en que ocupó el cargo- estuvo marcado por el signo de la construcción y las obras públicas. Desde su llegada a la alcaldía, en febrero de 1947, la instrucción era clara: construir para dar un nuevo rostro a la urbe de cara a la Conferencia Panamericana a celebrarse en 1948, pero también de cara al progreso mismo de la ciudad. Después del mes de abril de 1948 la tarea se presentaba como aún más apremiante: "reconstruir a Bogotá". La labor fue asumida, y en unos pocos meses ya se mostraban los primeros resultados, que eran reseñados por algunos con cierto asombro:

Piqueta en mano, el alcalde de la ciudad señor Mazuera Villegas, continúa su tarea demoledora. El prestigio de nuestros burgomaestres no se obtiene construyendo sino destruyendo. La ciudad que se sabe fea, no protesta ante las arremetidas del progreso y dinámica, que le dan el aspecto de una villa recientemente bombardeada. El público se complace en asistir al espectáculo de los "caterpillars" y los "Buldózeres" que con sus gigantescas 
manos metálicas desplazan los escombros de lo que fue la habitación[,] la residencia de millares de bogotanos. ("Ciudad arrasada", 1947, p. 4)

Los bogotanos, poco acostumbrados a este frenético ritmo de demoliciones, quedaban asombrados frente al dinamismo de su alcalde que había llegado para hacer "progresar" la ciudad. Todo era nuevo para el ciudadano de a pie que acudía impávido a la caída de lo que consideraba un pasado "miserable" y "vergonzoso". Los conatos de censura o cuestionamiento pasaban sin causarle daño alguno al alcalde, quien "ya estaba acostumbrado a que para poder crear hay que someterse a la justa critica y a todos los reproches de una sociedad que no está acostumbrada a un movimiento nuevo ni a ver que se le está impulsando en forma dinámica y progresista" (Mazuera, 1972, p. 221).

Algunos poco críticos alzaban la voz, no tanto por la realización de las obras, como por el parámetro urbanístico que guiaba la transformación. De esa manera, mientras las demoliciones, construcciones y ensanchamientos seguían su curso, un editorialista ofuscado afirmaba en estos años que:

Bogotá es una de las ciudades más inarmónicas del mundo, a causa de que nos hemos empeñado en la vana tarea de injertar a Norteamérica en la planicie de los Chibchas. El leit motiv de los alcaldes y concejales de los últimos lustros ha sido siempre el mismo, ampliar calles sin ton ni son. (Pardo, 1949, p. 4)

Y ciertamente había algo de verdad en la crítica de Pardo Umaña, pues las imágenes de ciudades estadounidenses, especialmente de New York, inundaban páginas de revistas y periódicos, de la misma manera que era común encontrar perfiles de la "capital del mundo" en películas de moda presentadas en los teatros de la ciudad. De ese modo, los bogotanos presenciaban:

en forma directa e incontrovertible, y a nivel masivo, la posibilidad de otras formas de vida, de mundos alternativos sin 
necesidad de viajar, desde una cómoda butaca, los bogotanos veían cómo el resto del mundo empezaba a hacerse presente en sus vidas [...] existía por primera vez una referencia, un parámetro comparativo donde situar la vida colectiva: el bogotano de repente se encontró más pobre, más provinciano, más cercano al mundo y a la vez más distante. (Arango, 1979, p. 88)

Como esa distancia mortificaba e incomodaba, el alcalde se convertía en una suerte de salvador. "Fernando el demoledor" era el título con el que los bogotanos habian investido a quien se suponía demarcaba la senda del progreso de la capital colombiana. Los hechos eran patentes, pues el alcalde Mazuera en una semana de 1947 mandó abajo toda la cuadra situada entre la carrera 13 y la carrera 7 , en las calles 30 y 31 , y la carrera 9, entre calles 24 y 25 ; abrió parte de la carrera 14 (av. Caracas) hacia el sur, y demolió las casas que comunican al patio del Capitolio. Pero todo era poco comparado con las obras del plan municipal para la Conferencia Panamericana; de 21 puntos, más de la mitad estaban asociados con la construcción, ampliación y pavimentación de vías (véase “Cuáles serán las obras...", 1946, p. 13).

La junta encargada de planear estas obras (y de administrar los 15 millones y medio de pesos destinados para tal fin) estaba integrada por el ingeniero Laureano Gómez, jefe de la sección de planeación, quien estaría acompañado por Manuel de Vengoechea, Carlos Martínez, Manuel J. Robayo, entre otros. Quizá la labor más apremiante de este grupo de personas constituía poner en marcha las obras de la colosal avenida de Las Américas, la cual fue "ideada dos años antes (1944) por la Sociedad Colombiana de Arquitectos, para descongestionar el tránsito hacia los municipios del occidente de Bogotá y hacer que las nuevas urbanizaciones se orienten nuevamente hacia el río y no sigan dispersándose a lo largo de las estribaciones de Monserrate y Guadalupe" ("Para la Panamericana", 1947, p. 18). Desde su concepción, la avenida se constituyó en una obra sin precedentes en el entramado vial de Bogotá y en un hito de la modernidad urbanística de la ciudad. 
Por ostentar esta condición algunas medidas especiales fueron tenidas en cuenta en el uso de esta vía; se previó, por ejemplo, la instalación de semáforos o señales luminosas sincronizadas, los cuales, conforme aumentara el número de vehículos que circularan por ella, debían ser instalados en los cruces. Adicionalmente, se exigía la eliminación de todos los elementos que obstruyeran el paso por la vía o afectaran su calidad estética, por lo tanto se prohibia "en ambos sentidos de la avenida el tránsito de ganado, aves, recuas conducidas por pastores o por jinetes. Igualmente no es permitido el tránsito de vehículos de tracción animal. Tampoco podrán transitar carritos, "zorras" o volquetas animadas por personas" (Ritter, 1946, p. 32). Estas medidas que en su momento no generaron mayor controversia, pocos años después fueron objeto de algunas protestas al tratar de imponerlas en el conjunto de vías de la ciudad. Un articulista manifestaba entonces que:

los humildes acarreadores de zorras no pueden entender por qué en nombre de la estética, se les prohíbe conducir su modesto vehículo por más de 50 calles centrales de la ciudad a partir de las 9 de la mañana. Desde luego las severas restricciones, impuestas por la alcaldía quieren hallar su fundamento en la necesidad de resolver parcialmente el problema de la congestión al tránsito, pero la buscada solución sería de tan insignificantes beneficios, que la única justificación aparente de la medida surge de preocupaciones meramente estéticas, como si se tratara de no darle al turista el espectáculo de la ruana proletaria y de la desmedrada carretilla por las calles más bonitas de la ciudad. ("Defensa de los 'Zorreros'...”, 1949, p. 4)

Pero este tipo de manifestaciones eran más bien pocas, si se le compara con el entusiasmo que generaba la construcción de avenidas como las Américas, la ampliación de la avenida Caracas o la construcción de la carrera $10^{\mathrm{a}}$. Era el entusiasmo que producía el movimiento, la velocidad, las subjetividades cinéticas, como las denominó Castro-Gómez (2009), tan importantes para la economía de mercado y para el ethos de una ciudad capitalista. 


\section{¿Para qué rieles si hay buses?}

Desde hace ya varios años, investigadores y académicos se han interesado por la historia del tranvía de Bogotá y la suerte que corrió durante los 67 años que estuvo en servicio. Se pueden mencionar las tesis de grado de Contreras y Restrepo (1985), Benítez (1997), Acosta y Baquero (2005) y Baquero (2009). Un trabajo ya clásico es el de Jaramillo y Parias (1995), así como el de Rodríguez (2003). Algunos han abordado el tema indirectamente, ya sea porque se encuadra dentro de una historia del transporte de la ciudad, como Montezuma (2000) o quizá uno de los más famosos, el de Aprile (1983), quien fue el primero en mencionar la tesis según la cual el fin del tranvía estuvo determinado por el accionar de personas vinculadas a empresas privadas del transporte durante los desmanes del 9 de abril de 1948.

Una tesis compartida por todos estos autores es que la liquidación del sistema de transporte sobre rieles fue una decisión apresurada y que bien hubiera podido continuar su operación durante un tiempo si los administradores hubiesen tenido la voluntad de hacerlo. De común, la afirmación se encuentra además ratificada por un pequeño párrafo extraído de las memorias de Fernando Mazuera, quien escribía que en un acto "un poco dictatorial" aprovechó los desmanes del 9 de abril para mandar pavimentar los rieles del tranvía por la Avenida de la República, "hasta el parque de San Diego" (Mazuera, 1972, pp. 249-250).

A pesar de lo contundentes que resultaban las afirmaciones de Mazuera, es probable que el fin del tranvía haya obedecido menos al impuso voluntarioso del alcalde de turno y más a una serie de eventos que habian comenzado a actuar en detrimento del ferrocarril urbano desde varios años antes del 9 de abril de 1948. El primero de ellos tenía que ver con las condiciones mismas del servicio: la cobertura, la capacidad y la velocidad, aspectos que una y otra vez le fueron criticados conforme la ciudad crecía. Para finales de la década de 1940, barrios del sur de la ciudad como el Inglés, San Carlos, Santa Lucía, El Centenario y Tunjuelito, o en el norte zonas como la del Chicó, El Lago y El Nogal no contaban con red de tranvía, a pesar de que eran áreas consolidadas y con miles de habitantes morando en ellas. 
Adicionalmente, se criticaba al mismo tiempo la capacidad del sistema; así, por ejemplo, entre los años de 1943 y 1945 la empresa del tranvía aumentó significativamente la cantidad de pasajeros transportados manteniendo estable el número de máquinas en servicio. Si para 1943 el tranvía movilizó cerca de 37544424 pasajeros, para 1944 la cifra ascendió a 43448 356, llegando en 1945 a 51499803 y en 1946 casi a 60000000 de pasajeros, trabajando durante este periodo con los mismos 93 carros.

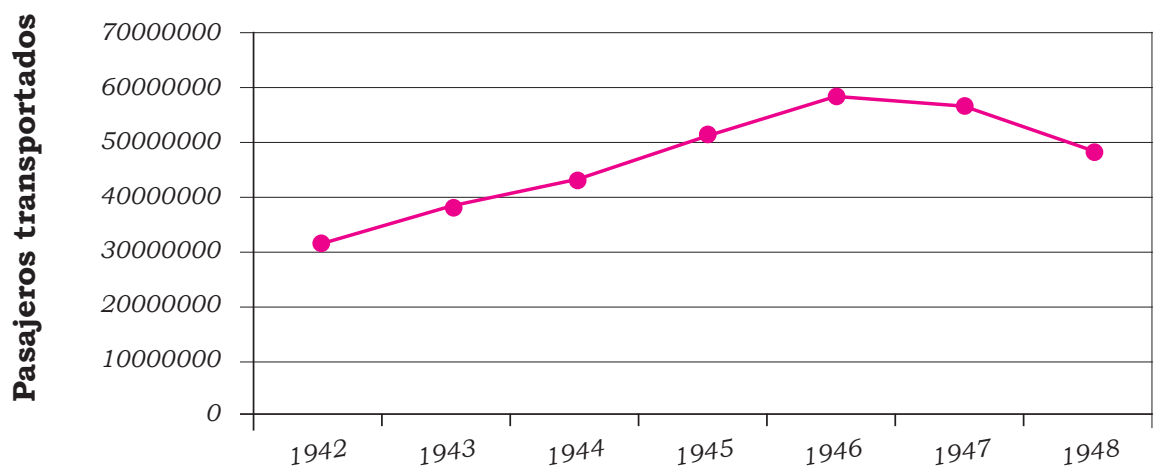

Año

Tabla 1. Cantidad de pasajeros transportados por el Tranvía Municipal de Bogotá 1942-1948

Fuente: Anuario Municipal de Estadística. Cálculos del autor.

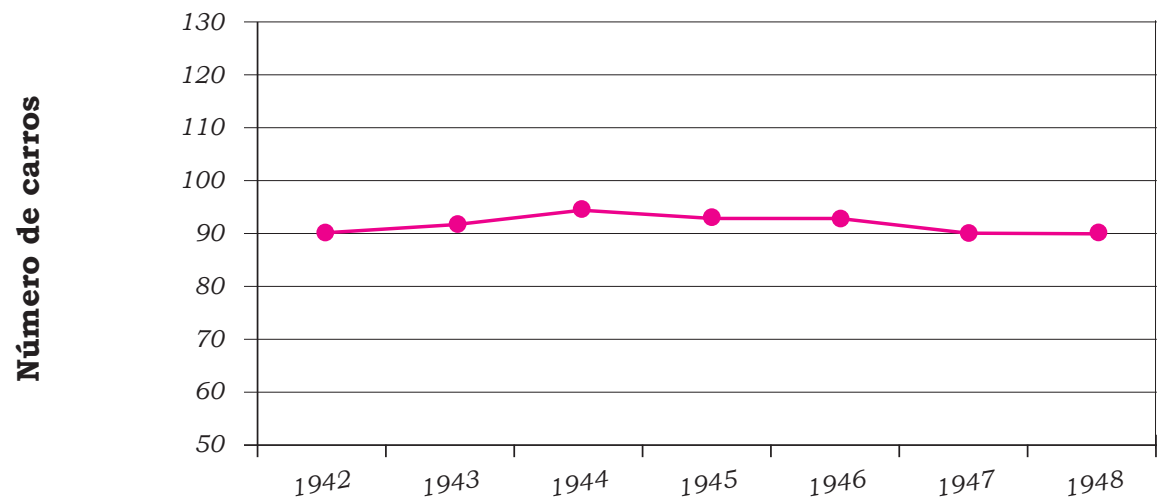

Año

Tabla 2. Número de carros del Tranvía Municipal de Bogotá entre 1942 y 1948 Fuente: Anuario Municipal de Estadistica. Cálculos del autor. 
Los problemas ocasionados por la Segunda Guerra Mundial para la importación de maquinaria, tuvieron como consecuencia el hecho de que la agresiva competencia llevada a cabo por las cooperativas de buses en contra de la empresa municipal de transporte viviera una tregua, esto debido a la escasez en la dotación de repuestos y llantas para los autobuses particulares, mientras que, por su parte, el "tranvia sobrellevó las dificultades con la existencia de repuestos en sus almacenes y con la experiencia acumulada de más de 30 años de ensamblar, reparar, y construir sus propios vehículos, así como de elaborar, cuando fuera indispensable las propias piezas de reemplazo" (Rodríguez, 2003, p. 140). Argucias en realidad utilizadas por muchos en Colombia, quienes ante la imposibilidad de adquirir nuevas máquinas o repuestos para los ya usados, echaron mano de todo el ingenio posible, por tanto "no era raro encontrar llantas aparentemente inservibles, reacondicionadas mediante relleno de paja, papel periódico u otros materiales, con lo cual quedaban transformadas en llantas macizas que de alguna manera solucionaban temporalmente el problema" (Villegas, 1995, p. 46).

La situación de la empresa del Tranvía Municipal se agravaba con los años. Poco a poco los reclamos y protestas por las formas de comportamiento poco amables y de descortesía que reiteradamente ocupaban las páginas de medios impresos, fueron dando paso a notas que se ocupaban de los preocupantes niveles de accidentalidad que diariamente se vivian por culpa del sobrecupo. Y si bien algunas voces reclamaban la necesidad de una ampliación de la red, cada vez eran más lo que sugerian que esa ampliación debería sustentarse en una flotilla de buses a gasolina o impulsados por corriente eléctrica.

También era claro que la aparición de cooperativas de buses que surgian espontánea y desorganizadamente, siguiendo la aparición de barrios clandestinos, iba en detrimento de los intereses del municipio. En consonancia con esta idea, Carlos Sanz de Santamaría, quien había sido alcalde de Bogotá, proponía adquirir el parque automotor de las empresas privadas y de esta manera continuar con el monopolio del transporte público urbano que redundaría en beneficio de los usuarios, pues aseveraba que: 
al tomar el municipio este servicio, todo el personal que hoy trabaja en los buses particulares ingresaría dentro de la organización municipal; se dotaría de uniformes semejantes a los del tranvía y podría organizarse la movilización urbana en forma económica, lo que hoy no puede hacerse por las dificultades inherentes a la competencia de la empresa del tranvia con las empresas particulares de transporte. (Sanz de Santamaria, 1944, p. 1)

Otras estrategias estaban orientadas a dejar en manos de la empresa privada la movilización de pasajeros. Algunos opinaban que había que adecuar la ciudad a las nuevas circunstancias de modernización, construyendo grandes y amplias vías y parqueaderos, con el fin de repercutir favorablemente tanto en el progreso del transporte masivo o colectivo, como de los usuarios de automóviles privados.

En el caso de los transportes urbanos el fin de la guerra creó el escenario propicio para que las cooperativas de buses urbanos que habian visto diezmadas sus posibilidades de hacerle frente a la empresa municipal de transportes, retomaran nuevamente la agresiva competencia que habian tenido que abandonar de modo imprevisto por causas del conflicto bélico mundial. Nuevamente podian modernizar su flotilla de buses con nuevas máquinas y reacondicionar las existentes con repuestos importados. En la tabla 3 se puede apreciar el impulso que se dio al negocio de los transportes privados inmediatamente después de que la guerra llegara a su fin, al tiempo que la empresa municipal no tuvo mayores variaciones en sus adquisiciones ni durante el periodo del conflicto bélico ni después de él.

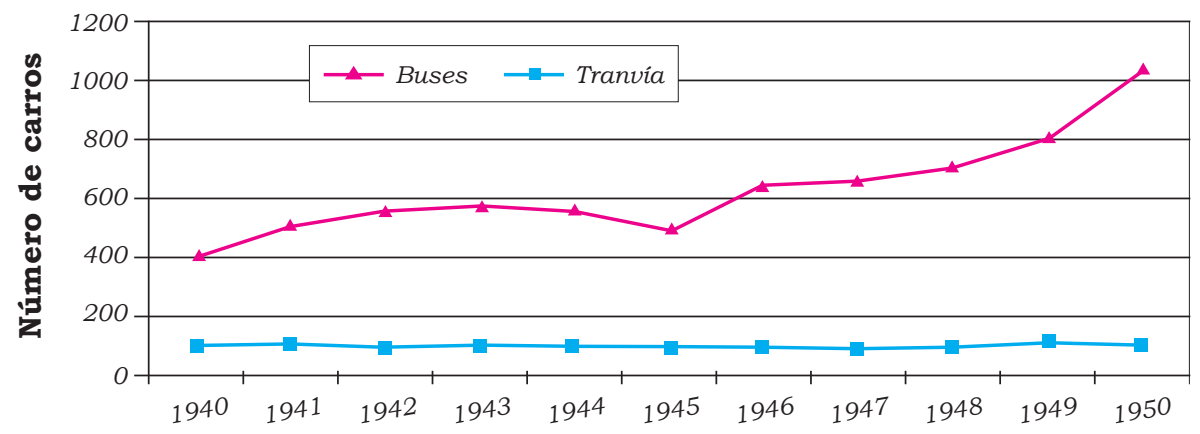

Año

Tabla 3. Cantidad de carros de tranvía y buses de servicio público en Bogotá, 1940-1950 Fuente: Anuario Municipal de Estadística. Cálculos del autor. 
Pese a esto, un año antes al 9 de abril se reseñaba a favor de la empresa del tranvía lo siguiente: "de 5:30 A.M. a 7 P.M. una de las asociaciones de transportes privadas, con 312 buses, acarrea 156000 personas y la empresa del tranvía en el mismo tiempo (con 100 carros) tomaba 163000 pasajeros" (Aprile, 1983, p. 84).

Pero eran tiempos de cambios repentinos e imperturbables, la ciudad se extendía conforme su población iba en aumento, y pronto la esfera de influencia se estableció mucho más allá de los tradicionales límites urbanos, donde solo podían aparecer barrios ilegales con los subsecuentes problemas que una urbanización de este tipo traería. En palabras de Hernando Téllez, "era una etapa de la adolescencia, equivalente a aquella que en los seres humanos no permite adivinar con exactitud el límite entre lo que se abandona y lo que se adquiere, entre lo que se es y lo que se empieza a ya no ser" (Téllez, 1978, p. 164). En este contexto el ferrocarril urbano se iba haciendo ineficiente frente a los buses a gasolina, en su mayoria administrados por empresarios privados, quienes gracias a la flexibilidad e informalidad derivada de su modelo de negocio podían fácilmente llegar a la periferia de la ciudad por nuevas carreteras y vías generalmente en mal estado.

Desde la perspectiva de quienes regían los destinos de la ciudad, esta incapacidad para ampliar la red de cobertura se debía en parte a motivos económicos, pues "la empresa tranviaria no cuenta con divisas para importar nuevos materiales y por esta causa no logra extender sus líneas a los más lejanos barrios obreros. En el Concejo después de una intervención de Rafael Castillo se aprobó una moción para pedir que la cobertura no prosiguiese" ("Bienes ocultos", 1948, p. 12).

Ya después de 1948 es evidente que las condiciones han cambiado, ahora la "empresa del tranvía municipal de Bogotá con sus 70 tranvías y 40 autobuses transportaba un promedio diario de 163000 pasajeros. El promedio para las empresas privadas de transportes colectivos con 650 vehículos asciende a 350000 pasajeros" (“Los transportes urbanos...", 1949, p. 34). 
No obstante, el fin del tranvía fue estimulado por la misma administración municipal cuando decidió adoptar un modelo de modernización de la ciudad en donde el ferrocarril urbano ya no cabía; se pensó entonces que la mejor salida era cambiar el sistema a cómodos y rápidos buses a gasolina, pues "los buses eran un medio de transporte en auge en todos los países del mundo. Era un sistema más flexible, no sólo desde el punto de vista técnico, sino por las relaciones sociales que lo sustentaban". Adicionalmente, y aunque no es posible saberlo con precisión hay serios indicios que "muestran que habia en los años cuarenta una presencia considerable de pequeños propietarios" (Castañeda, 1997, s.p.) que sabian de lo lucrativo del negocio y estaban dispuestos a pelear no solo por mantener sus privilegios sino por seguir ampliándolos, una tarea no muy complicada en medio de la indiferencia estatal hacia la administración de este servicio público.

No obstante, para algunos las circunstancias obligaban a que el sistema de movilidad cambiara, pero no consideraban del todo necesario acabar con la empresa municipal y más bien buscaban mantenerla viva proporcionándole una nueva imagen; en un extenso informe presentado a la Sociedad Colombiana de Ingenieros se aseguraba que:

la solución de suprimir el tranvía es al parecer contradictoria. Paréceme que deben existir permanentemente varios sistemas de transporte en la ciudad, entre ellos los llamados tranvias [...], no estimo prudente suprimir un sistema, sino modificarlo, si es necesario, como por ejemplo, instalando buses de Trolley, venidos del exterior y que haya coordinación de sistemas. (Uribe, 1947, p. 168)

Pero esta coordinación no ocurrió, e incluso el fin del tranvía había comenzado a plantearse varios años antes del Bogotazo (fecha que una y otra vez se ha señalado como la determinante de la supresión del servicio). De hecho, en 1946, el Concejo de la ciudad había determinado acoger el plan de modernización del tranvía propuesto por la junta directiva de esta empresa municipal. Este plan incluía "Adquisición de buses trolley para hacer el recorrido de las 
vias en donde existe actualmente servicio de tranvía, sin extenderlo a otras calles y avenidas", del mismo modo se autorizaba "la Instalación de un servicio de buses de gasolina o aceite" e iniciar estudios para "el establecimiento de un servicio de ferrocarriles o tranvía subterráneo en la ciudad" (Registro Municipal de Bogotá, 1946, Acuerdo N. $\left.{ }^{\circ} 10\right)$.

Estas disposiciones fueron implementándose paulatinamente y cada medida que actuaba en perjuicio del tranvía era vista como un avance en la senda del "progreso". Sobre la inauguración del servicio trolley se decía en la prensa: "Bogotá continúa modernizándose. Esta mañana (octubre 6 de 1948) comenzó a prestarse el servicio de buses Trolley a lo largo de la avenida Caracas con terminal en la avenida de los Mártires. Un punto a favor de la ciudad que cuenta ya con estos modernos vehículos municipales" (“Los buses-trolley...", 1948, p. 3).

Cada una de estas campañas reafirmaba la percepción del tranvía como un sistema de transporte de otra época en el que "todo tiempo pasado fue más lento" ("En tranvía...", 1948, p. 10), por esa razón no resultó extraño que "la llegada de los autobuses a la carrera séptima fuese acompañada de una operación de descrédito del tranvía el cual era mostrado como obsoleto y pasado de moda" (Montezuma, 2000, p. 54), una estrategia que si se juzga por lo que consiguió, resultó exitosa.

La campaña de descrédito se acompañó además del desmonte de ciertos beneficios que el sistema ofrecía a los ciudadanos más pobres. Tal fue el caso del tranvía obrero que antes de ser suprimido subió su tarifa de $\$ 0.02$ a los $\$ 0.07$ y alcanzó la cifra de $\$ 0.10$ estableciendo un incremento constante cada año. Otro tanto ocurrió con los escolares, quienes tenían el derecho de viajar gratis en este medio de transporte en época de actividad académica. Las disposiciones que afectaron directamente a esta población se reseñaron en una crónica de la época:

Solo en tranvías abiertos pueden viajar las niñas de colegio. Las pequeñas colegialas que tienen que hacer uso de los tranvias para ir 
a sus establecimientos y para regresar a sus casas, se han hallado ante otra medida absurda que hace parte de la cadena descabellada implantada por la administración del tranvía: las niñitas solo pueden viajar en tranvías abiertos, únicos en los cuales se les reciben los tiquetes escolares. Hasta hace poco se les permitía el viaje en los tranvías cerrados, pero entregando dos tiquetes por cada viaje; ahora se ordenó que las niñas deben ser relegadas a los populares e incómodos tranvías abiertos lo cual no deja de representar un grave peligro. (“Sólo en tranvias...", 1949, p. 3)

Así, poco a poco la prestación del servicio de transporte sobre rieles fue perdiendo el prestigio y la capacidad para atender el desarrollo de una ciudad que se extendía más allá de los confines de sus propios límites. Transcurridos tres años desde que comenzaran a rodar por Bogotá los primeros buses trolleys, el viejo sistema de movilidad sobre rieles que había aliviado los problemas de transporte urbano por más de medio siglo, sucumbió bajo la impostergable búsqueda de modernización y velocidad que tan afanosamente querian alcanzar la ciudad y sus habitantes.

Esta situación llevó a que en 1951 la última línea del viejo ferrocarril urbano que se encontraba en funcionamiento llegara a su fin, fue así como

el sábado 30 de junio, los últimos 8 carros del tranvía que prestaban servicio en Bogotá, en la línea de los barrios Pensilvania y 20 de Julio fueron archivados y remplazados por grandes y generalmente silenciosos buses White. La desaparición de los ruidosos vehículos canceló una etapa de desarrollo de los servicios de transporte en Bogotá. (“Descanso”, 1951, p. 7)

La supresión del sistema se llevó a cabo sin mayores protestas o contratiempos. Según reseñó la prensa local:

puede decirse que desde ayer quedó suspendido el servicio de tranvía. Efectivamente, cuando los conductores y cobradores de los tranvías de la ruta Pensilvania - 20 de Julio supieron que el 
servicio iba a ser suprimido, resolvieron suspender labores a excepción de un conductor que continuó viajando de un lado a otro en tranvía. (“Suprimidos los últimos...”, 1951, p. 6)

Con relación a este final, es de resaltar que la clausura de este medio de transporte para muchos ciudadanos representó el fin mismo de un tipo de ciudad encarnado en el viejo sistema de movilidad, pues:

la época del tranvía fue familiar[,] esencialmente hogareña, ajena a la terrible soledad de las multitudes metropolitanas. La clausura del tranvía puede interpretarse como el paso de la Bogotá bogotana a la Bogotá universal. Ya no habrá sitio para la tertulia ni para el simple deleite de la amistad desinteresada. En cambio, se multiplicarán los compromisos, los espectáculos, la ciudad plena, sin un atisbo de los sabores campesinos. Vivimos en la ciudad del Mack, del saludo sin emoción, de la emoción standard. ("Ha muerto el tranvía...", 1951, p. 7)

El cambio del modelo de transporte público fue más complejo de lo que con frecuencia se afirma. Ciertamente los intereses privados promovieron sus negocios, pero también es cierto que para muchos bogotanos el sistema no suplía las condiciones mínimas de calidad, cobertura y velocidad. A finales de la década de los cuarenta parecía haber un consenso tanto en la necesidad de ensanchar y construir vías, como en la opinión negativa sobre el tranvía. Esta visión pesimista sobre el tranvía se extendió en general a todo el sistema de movilidad urbano. Sin duda parecía que el cambio y la modernidad tenian consecuencias, y los bogotanos comenzaban a percibir que el precio de sus aspiraciones podría ser muy alto.

\section{Bajo las llantas del progreso}

La masificación demográfica se acompañó de la masificación vehicular. En apenas catorce años el número de vehículos en la ciudad se multiplicó por seis, como se muestra en la tabla 4. 


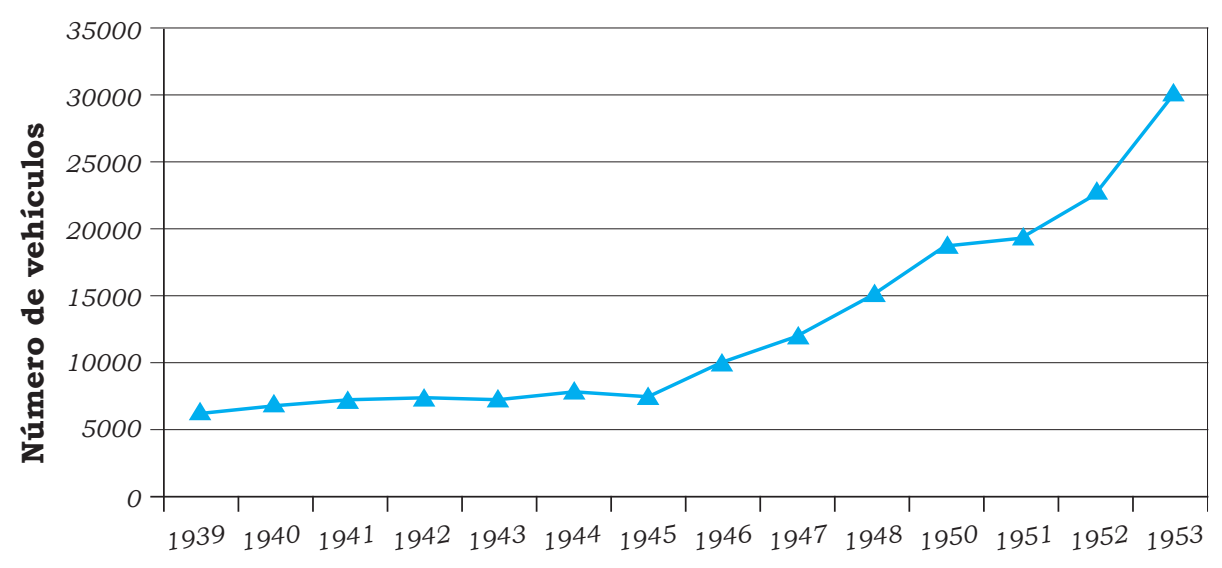

Año

Tabla 4. Número de vehículos en circulación en Bogotá, 1939-1953 Fuente: Anuario Municipal de Estadística. Cálculos del autor.

El número de 30000 vehículos corresponde a todas las categorías: buses, camiones, autos, tracción animal, etc. Los automóviles y buses eran ya parte del paisaje cotidiano de la ciudad, así como los accidentes, el caos y el desconcierto. Ante el desafio de enfrentar estas situaciones inéditas, en 1939 el Departamento de Circulación y Tránsito planteó una campaña denominada la Semana de la Cortesía, la cual pretendía hacer resurgir en los conductores y peatones las buenas maneras en el trato y en las relaciones que día a día, y obligatoriamente, se tenían que entablar en la calle. En concordancia con esto se reseñaba en la prensa de la época que:

la semana de la cortesía perseguía una elevada finalidad: hacer que el conductor y el peatón se dieran la mano y que de este diálogo resultara una nueva especialización urbana: la cultura automoviliaria. En realidad, los textos de urbanidad consultados hasta el momento, particularmente el del señor Carreño, no preveían esto que pudiera llamarse la posición del hombre ante el automóvil, del automóvil ante el hombre ("La semana...", 1939, p. 28)

Para los encargados de la regulación del tráfico de Bogotá en este periodo, parecía claro que las causas principales de los accidentes 
de tránsito eran la falta de modales y buen comportamiento de los ciudadanos, tanto en los tranvias, como en los buses urbanos, automóviles particulares y aceras.

Algunos comentarios con aire mordaz, suscitados por los siete días de cortesía, fueron tema de algunas páginas centrales de medios impresos que anotaban los hechos ocurridos de la siguiente manera:

Un simpático tenorio va a la cabrilla. Una dama deja caer en estos momentos su cartera a la calle y el joven conquistador la convierte en una estampilla contra el suelo. La dama da un grito cortado. Se le oye una marca como de "rouge".

-¡Oh! Perdón. -Dice el caballero.

-No tenga usted cuidado. Fue culpa mía. Lamento una cosa, mi lápiz para los labios era único.

-Un porte tan exquisito no necesita del cosmético.

-Qué gentil.

Un ademán versallesco del caballero. El ingenioso cachaco surge entonces y dice:

-Qué refinamiento. Hemos inventado el carterismo automoviliario.

[...] pero no todo era humorismo, Versalles no estaba sino en el centro. En la periferia de la ciudad los accidentes se presentaban con toda normalidad. Con una diferencia los peatones reconocían su error y se abstenían de dar su denuncia ante los juzgados. ("La semana de...”, 1939, p. 28)

Esta campaña se explicaba no solo porque se percibía una cierta falta de modales y una suerte de caos iniciático, sino también porque durante estos años los accidentes de tráfico se incrementaron. Solamente en el año de 1938, los fallecimientos por esta causa 
alcanzaron su punto más alto: murieron cerca de 78 personas, por ello las acciones y las campañas emprendidas para tratar de amoldar al pueblo a los cambios que experimentaba la ciudad se volvieron recurrentes; se presentaban casi con la misma regularidad con la que son denunciadas la pérdida de la delicadeza y elegancia en los modos de actuar en público, especialmente en el ámbito de la movilidad y el transporte.

La falta de buenas maneras era para algunos el gran problema del transporte público; sobre el tranvía se decía:

Con los tranvías llegaron los tumultos y dentro de ellos mucha falta de modales. [...]. Y es que aquí en Bogotá no se ha sabido apreciar los inventos. ¿Se ha visto muestra peor de mala educación que aquella que consiste en viajar en un tranvía cómodamente sentado, mientras muchas señoras tienen que someterse al bamboleo consecuente con un tránsito mal establecido? [...] No se necesita sino ser una persona medianamente viajada para poder afirmar como Dios manda, que aquí el grueso público -ya que claro hay excepciones- se comporta con los peores modales. Y no es porque no sepa literatura, ni música, ni escultura. No, es porque quiere ser maleducado y los desarrollos y los inventos se adelantaron a la educación de la población. (Carnes, 1941, pp. 17-38)

Se presumía que la cortesía, las buenas maneras y la "buena educación" se estaban perdiendo, y por eso no era raro encontrar en las revistas una solicitud a los lectores para hacer un examen de su conducta y preguntarse si:

se dirige como un loco hacia un puesto vacío empujando jóvenes, mujeres y ancianos, a derecha e izquierda. O si ocupa dos asientos, uno para usted y otro para sus pies. Usted entabla conversación con extraños para luego gritar y encolerizarse cuando se entera de que vota por otro candidato; o es un lector de aquellos que mira por todos los lados el periódico del vecino, o no cede cortésmente el puesto a una dama. (“¿Y sus modales...?”, 1940, p. 14) 
Todas estas conductas de pésimo gusto debían ser evitadas por alguien que se preciase de tener algo de educación. A los conductores de automóviles además se les aconsejaba expresamente:

no ser un Pablo Revére mecanizado que asusta a los amigos pasándoles cerca a toda velocidad y sin dejar de pitar. No es aconsejable tocar la sirena y pasar muy cerca de los autos detenidos y de los peatones. No sea usted de esos estúpidos temerarios que asusta a los paseantes no aplicando los frenos sino cuando ya los va a atropellar. Tampoco sea de los que insultan a los otros conductores y amenaza con llamar a la policía. No sea de los que pita cuando llega a la casa de alguien que le está esperando. (“¿Y sus modales...?”, 1940, p. 14)

Es significativo anotar que las normas de seguridad automovilística se confundieran con normas de cortesía. De alguna manera en este momento no solo importa la vida del peatón, sino que también cumple un papel fundamental la buena impresión que el habitante urbano cause con sus comportamientos. Con todo, para este periodo la ciudad ya contaba con normas formales de circulación, expresadas en un código; su introducción, sin embargo, va a ser lenta y en no pocas ocasiones problemática, debido en parte a que la implementación de estas normas implicaba el uso de cierta simbología a la que muchos de los habitantes de la ciudad aún no estaba acostumbrados, tal fue el caso de "los semáforos que estuvieron muchos meses guardados en un rincón de la oficinas de la dirección de circulación, debido a que las gentes no se han podido acostumbrar a las órdenes obligantes de las lucecitas. El verde o el amarillo y el rojo nada les dice” (Moreno, 1941, p. 22).

En vista de que las normas expresadas en códigos eran letra muerta, se solicitaban maniobras más efectivas para orientar al grueso de la población a comportarse adecuadamente en las calles y avenidas de la ciudad. Se declaraba entonces que la mejor estrategia era:

la educación: todos los conductores, todos los peatones, niños y viejos, jóvenes y mujeres, debieran ser educados en los problemas 
del tránsito; el cinematógrafo puede servir para educar a los adultos; en las escuelas se debe dedicar algunas horas al mes a esta enseñanza. Esta campaña educativa será infinitamente mejor para disminuir los accidentes, que el famoso artículo del código penal que es sencillamente monstruoso en la práctica. ("El tránsito un problema incipiente...”, 1939, pp. 28-29)

Pero la amabilidad, cordialidad y buen trato no eran aspectos que se suponía deberían tener en cuenta exclusivamente los peatones y los conductores de autos, los prestadores de servicio de transporte colectivo en estos años también se debían preocupar por las buenas maneras. Así lo dejaban entrever algunas medidas tomadas por la junta directiva de la empresa Municipal del Tranvía. En ellas se indicaba al cobrador del tranvía la manera en que debía dirigirse a los pasajeros, es decir, "con suavidad y educación"; adicionalmente, debían ayudar a los ancianos y niños, así como convertirse en guardianes de las formas corteses, dado que estaban en la obligación de "llamar la atención con toda cultura a cualquier pasajero que en el carro no aguarde la compostura que le es obligatoria" (Reglamento, 1941, p. 41).

No obstante, aunque las reglas fueran muy claras y su incumplimiento acarreara sanciones económicas a los empleados que las violaran, durante estos años las normas que regian la forma de obrar de los cobradores rápidamente cayeron en desuso. Al cobrador comenzó a identificársele con un personaje disociador, de malas costumbres y cierta dureza en sus maneras de tratar a los pasajeros del viejo sistema de transporte; algunos comentarios anotaban que:

en tanto el tranvía rueda con su carga humana indiferente a todo, los cobradores con ágiles movimientos, van cumpliendo su cometido. Algunos no son precisamente modelos de cultura: -El señor me hace el favor... ahí la señora, la niña. -Fíjese un poco hace ya siglos que le pagué, -Mis vueltas -Qué me dio la señora -Un billete de a peso. -Pues tiene que esperarse porque no tengo suelto. - Estos tranvías son una mugre. (Abello, 1940, pp. 40-41) 
Pocos años después la crítica continuaba siendo implacable con los cobradores; un articulista de la época se refería a ellos en los siguientes términos:

¡Ah!, pero me faltaba lo peor y principal. Me faltaban los cobradores. Estos no son tales cobradores, sino auténticas lanzaderas. Es de verlos de aquí para allá, de allá para acá, gritando, hurgando, "sobando" a todo el mundo y cobrándole a cada pasajero los cinco centavos veinte veces cada dos minutos cuando el carro está ya repleto, pues lo curioso es que mientras la gente comienza a entrar, ellos se aplanan en el mejor puesto de la entrada, se ponen a fumar y a dárselas de dueños de la "Nemesia". (Ibero, 1945, p. 13)

El hecho palpable era que la mezquindad atribuida al cobrador no solo se debía a su falta de consideración con los pasajeros, sino también a la inconformidad de muchos bogotanos con las reglas de regulación, como la de la detención en sitios demarcados, a lo que se le sumaban las dificiles condiciones en las que se viajaba debido al aumento de la demanda. Igualmente, las tensiones sociales se intensificaron, lo que conllevó a que el enfrentamiento fuera más volátil entre la ciudadanía y los empleados del tranvía, de quienes se decía eran ajenos a las reglas de urbanidad; muchos se preguntaban con disgusto "por qué razón no se les exige a los conductores y cobradores de todos los tranvias, que estén afeitados, que tengan las manos limpias y que sean corteses con el público que, al fin de fines, es el que sostiene a la empresa" (“Cinco preguntas...", 1946, p. 28).

En la convivencia cotidiana de ciudadanos de toda índole, y conforme pasaban los años, el problema de los transportes parecía no ceder ni un ápice en el agobio a los habitantes de la urbe. Ya no se trataba solamente de la "descortesía y la mala educación", pues a ello se sumaban los tumultos, la incomodidad y la demora, problemas que al promediar la mitad de la década de 1940 parecían acabar hasta con la paciencia del más resignado de los bogotanos. El semblante dramático al problema se lo imprimieron los mismos usuarios que diariamente hacian uso del insigne aparato, hechos que quedaron consignados en los comentarios de un articulista: 
-Oiga se tiró la embolada.

-Permiso, permiso que voy a bajar.

-Pare, pare, está sordo me pasó una cuadra.

-iAh! Por miserables cinco centavos quiere que lo deje en la puerta de su casa.

-Viejo asqueroso qué está creyendo que mis rodillas también son asiento.

-Me quemó la falda con su chicote. Deje de ser un patán.

-Ayayay, quién me pellizca. Patanes, groseros, marranos. Debían fijarse con quién tratan.

-Hombre no sea bestia, pase con cuidado que no está arriando mulas.

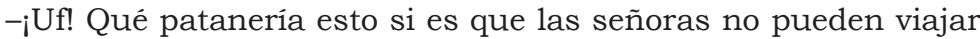
en tranvias

Por qué los anteriores pregones y dichos, gritos y exclamaciones, protestas y berridos, y percances y directas e indirectas, como ya lo habrán cogido desde la primera sílaba los lectores bogotanos, tienen lugar no en una casa de orates sueltos, ni en cualquier plaza de mercado, ni en una trastienda llena de borrachos sino lisa y llana y diaria y nochemente en el seno estrecho y tambaleante de uno de esos aparatos de tortura de ruedas casi cuadradas que las empresas municipales llaman tranvías. (Ibero, 1945, p. 13)

Eran muchos los comentarios satíricos que aludían a las dificultades de viajar en tranvía debido al enorme número de gentes que hacían uso del servicio. En un texto de 1944 se dejaba consignada tal situación: 
El lunes a eso de las siete de la noche tomé un tranvía. ¿Tomé un tranvía dije? Bueno pensé tomarlo. Me paré en la esquina. Se detuvo un carro de tipo cerrado. Y no recuerdo más. Apenas si surge[n] de entre la bruma de mi recuerdo algunos pensamientos extraños y confusos. Como el de una fuerza invisible e irresistible que me lanzó, como un proyectil, por entre las masas de viajeros que obstruian la entrada. Más tarde supe que tal fuerza estaba compuesta por sesenta aspirantes a pasajeros que pretendieron ingresar al tranvía al mismo tiempo que yo y por la misma puerta. Recuerdo que entre gritos, protestas, maldiciones, arañazos, codazos, empellones, mordiscos y crujir de telas desgarradas, me encontré de pronto sentado sobre las rodillas de una hermosa empleada, que reposaba sobre las de un caballero que a su vez ocultaba a una venerable dama bajo la cual se encontraba el cobrador. ("Algo sobre el tranvía...", 1944, p. 12)

En esta nueva ciudad de mitad del siglo, todo cambiaba, hasta el sentido con que se recorrian sus calles, pues "ahora es un asunto de vida o muerte: la calle es el peligro, el riesgo, lo desconocido, lo súbito, lo intempestivo. [...] Como diría un relato periodístico de los años 50, en la calle ya no hay lugar para el distraído: en un veloz bus, en un ruidoso automóvil o en una oscura esquina acecha la muerte" (Noguera, 2000, p. 25). También el espacio público se trasformaba; si cuarenta años antes los aparatos móviles permitían la sociabilidad, pues sin problema vehículos y ciudadanos compartian la calle, ahora la llegada en grandes proporciones de automotores impulsó una resignificación, como por ejemplo la apertura de la antigua calle Real al tráfico. Un periodista aplaudía la propuesta alegando que: "lo que el municipio debe hacer para descongestionar calles del comercio no es pensar en nuevas avenidas, algunas de ellas utópicas, sino gravar con un fuerte impuesto a los hombres sin oficio que instalan la tertulia política o el observatorio erótico en las aceras, generalmente a las puertas de los cafés" ("Se pide impuesto...", 1949, p. 9).

Esta queja llevó a que en 1948 se propusiera abrir la carrera $7^{\mathrm{a}}$ al tráfico automotor. No obstante, las protestas de la ciudadanía y de algunos políticos dieron al traste con la iniciativa; algunas declaraciones dan cuenta de ello, como la de un representante del departamento de Caldas, que afirmaba "yo, por ejemplo, he venido al 
Congreso [de la República] no para estar aquí entre estas cuatro paredes del capitolio, sino para tener la satisfacción de pasearme por esa zona de tranquilidad que es la carrera séptima"; o la de algunos conversadores del café La Cigarra, quienes afirmaban "es una medida descabellada. En todas partes existen zonas reservadas para el peatón" ("Alcalde ordena...", 1948, pp. 1 y 4).

A pesar de todas estas protestas en contra de la iniciativa, casi un año después y con los profundos inconvenientes de circulación y movilidad en Bogotá, la séptima, entre la calle 11 y la avenida Jiménez, daría paso a los buses urbanos. Entre los descontentos -dueños de cafés, vendedores ambulantes, loteros etc.-, los más inconformes fueron los amantes de la charla vespertina que tendrian que irse -como titulara una foto de la revista semana- "con la tertulia a otra parte".

En el caos de la movilidad aportaban diferentes actores. Por una parte, los conductores de servicio público violaban las normas de tránsito de manera impune, causando las mortales consecuencias de estos quebrantamientos. De acuerdo con un artículo de la revista Semana: "los buses paran en cualquier parte, aun en las bocacalles, al tomar o dejar pasajeros, sus conductores a veces marchan con tan desesperante lentitud o aceleran como para una carrera de velocidad. A veces tratan de pasar a otros vehículos aun subiéndose en la acera" ("Lucha por la vida...", 1949, p. 11). No era fácil descubrir al infractor, las violaciones eran tantas y los policías tan pocos que muchas veces la municipalidad se encontraba impotente para hacer cumplir lo que en códigos y normas había sido promulgado.

Por otro lado, una situación similar se experimentaba con los conductores de automóviles, estos no podían salvar su responsabilidad en los graves problemas de accidentalidad que progresivamente dejaba una cantidad considerable de personas fallecidas. Con respecto a ellos se argumentaba que:

los automovilistas particulares (aficionados) cometen errores como el de frenar intempestivamente, cruzar sin sacar la mano, o sacándola tantas veces y a destiempo que es imposible adivinar cuándo 
lo hacen por gusto y cuándo por cumplir el reglamento, incluso es posible encontrar aspectos pintorescos como el que en algunas calles el tránsito se paralice, causa: los conductores se han detenido a observar un encuentro de boxeo entre dos gamines. ("Lucha por la vida...", 1949, p. 11)

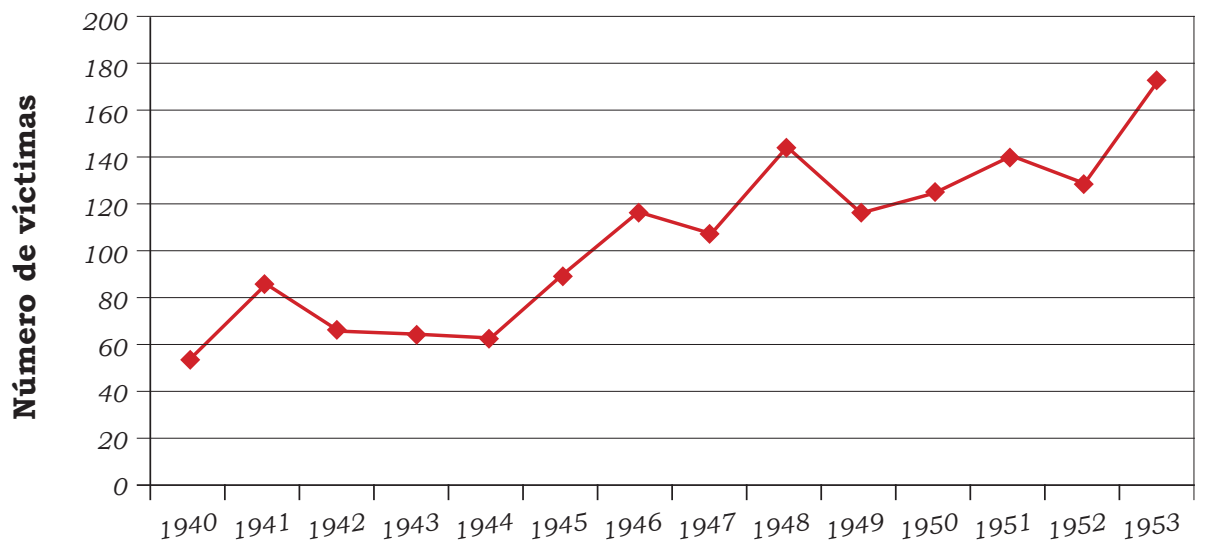

Año

Tabla 5. Personas muertas en accidentes de tránsito en Bogotá, 1940-1953

Fuente: Anuario Municipal de Estadística. Cálculos del autor.

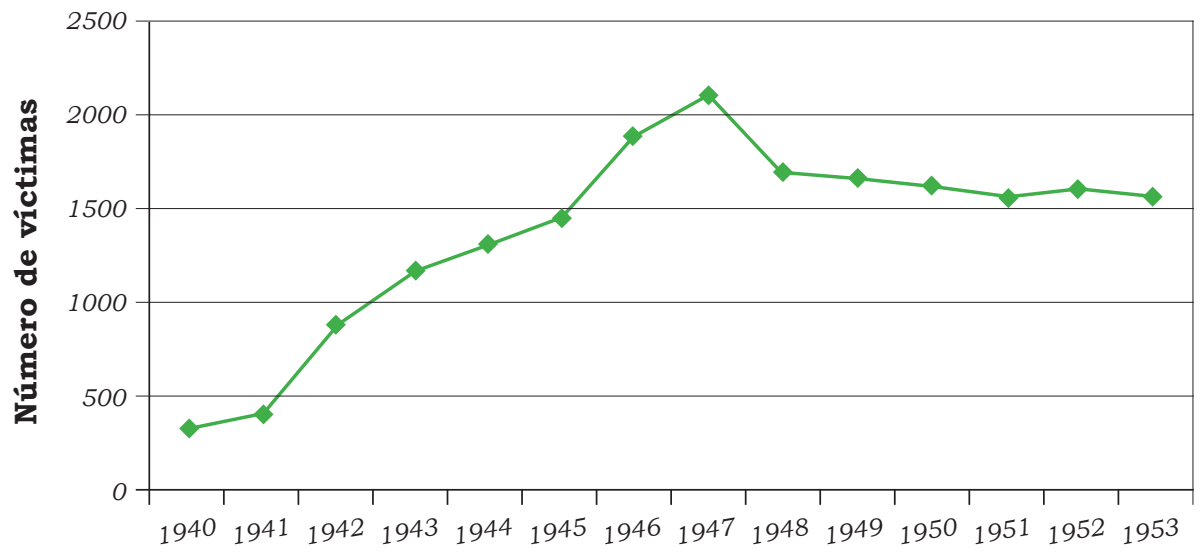

Año

Tabla 6. Personas heridas en accidentes de tránsito, 1940-1953

Fuente: Anuario Municipal de Estadística. Cálculos del autor. 
Siguiendo con el mismo argumento, algunos consideraban que las violaciones arbitrarias a las normas de tránsito no solamente se debían a la soberbia de conductores y choferes mal entrenados, y que la principal causa del aumento en la accidentalidad era el desconocimiento por parte de los habitantes urbanos de las reglamentaciones de tránsito. Por ello, en 1947 se insiste en la necesidad de educar desde la escuela en asuntos relacionados con la movilidad y el tráfico urbano:

Indicamos que en la clase de Enseñanza cívica en todas las escuelas y colegios, públicos y privados, se deben dedicar unos minutos siquiera, todos los días, a la explicación a los niños y a los jóvenes de la manera como debe portarse, no sólo un chofer, sino un peatón en las vías públicas. Pues de sobra conocemos todos los que tenemos que conducir vehículos, que la mayoría de los accidentes, así como las demoras, se deben a la falta de educación cívica de los peatones, que suponiendo que es muy elegante dárselas de valientes y despreocupados, se atraviesan delante de los carros, esperando muy probablemente que la niña de sus encantos quede fascinada ante su heroica actitud. (Andrade, 1947, p. 76)

A pesar de estas peticiones, las víctimas continuaban incrementándose conforme los años transcurrian, por esa razón, en 1949 se llevó a cabo la segunda versión de la Semana de la Cortesía. No obstante, las diferencias con la campaña de 1939 parecían saltar a la vista. Ya no se trataba de buscar la mejor salida a la desorientación que creaba el no tener un manual de urbanidad como el de Carreño, que diera pautas de cómo comportarse en la ciudad. Por el contrario, se buscaba encontrar los medios más idóneos para que los ciudadanos conocieran y asumieran las normas legales, y creyeran en el valor que encerraba respetarlas, pues hacerlo podría salvarles la vida.

Se leía en los considerandos del acuerdo que se buscaba: "crear hábitos de disciplina social y espontánea subordinación a la ley por el empleo de métodos de convicción directa como sustitutos de la coerción"; también que las autoridades debían acompañar la 
campaña con actos de benevolencia "para convencer mejor al pueblo de que la subordinación espontánea a la ley, es al mismo pueblo al que más conviene" (Anales del Concejo de Bogotá, N. ${ }^{\circ} 1785$, Acuerdo N. ${ }^{\circ} 59$ de 1949).

Durante una semana, el departamento de Circulación y Tránsito, desde donde partió la iniciativa, se propuso, según la revista Semana: "enseñar a las gentes algo aparentemente elemental, pero que es un verdadero arte en las ciudades modernas, a andar en la calle y a evitar los atropellos de los vehículos" "Guía de caminantes", 1949, p. 12). Así mismo, días antes de lanzar la campaña, por toda la ciudad fueron repartidos cerca de 600000 ejemplares del Código de peatones y casi 50000 ejemplares del Código del conductor; se adelantaron varias jornadas de explicación en escuelas y programas de radio, al tiempo que en los teatros se transmitian imágenes de sensibilización como preparación para los actos de la Semana de la Cortesía. Sin embargo, intentos como estos resultaron infructuosos pues, como se sugirió en los medios escritos de comunicación en relación con la campaña, "algunos buses han atropellado a varias personas sin mucha cortesía". Uno de los artículos sostenía que:

La regla más simple de la tauromaquia, dice: "o te quitas tú o el toro te quita a ti". Igual ocurre entre peatones y vehículos. O se quitan aquellos o estos los quitan. Y a pesar de que durante la semana de la cortesía, el director de tránsito Alfredo Ángel Tamayo ha querido enseñar a las gentes a quitarse, estas no lo han hecho y los automóviles los han quitado. [...] No fueron pocos los accidentes en la última semana. Al parecer, la cortesía era de los peatones para los automotores, pues había que darles paso, como siempre a toda costa. Pero los que no tuvieron esta cortesía fueron a dar al hospital. Con buenos consejos simplemente como que no se evitan las tragedias de tránsito según se pudo demostrar en la "semana de la cortesía”. (“Cortesía sin frenos”, 1949, p. 14)

Con éxito o no, es claro que en 1949 el castigo por realizar ciertas acciones como pasar a alta velocidad en un auto para asustar 
a un amigo, no será el que sus conocidos lo califiquen de maleducado o como un individuo falto de modales, sino que este mismo acto puede acarrearle alguna sanción legal. Así, si diez años antes se aseguraba que accionar la bocina para llamar a alguien a quien se iba a recoger a su casa constituía un acto de muy mala educación, ahora, aunque posiblemente seguía siendo de pésimo gusto, se le sumaba que era un delito que podía acarrear al contraventor el pago de una multa; algunos artículos de un acuerdo, promulgados en 1949, son un claro ejemplo de ello. En dos de estos artículos se disponía para efectos de la tranquilidad pública que:

Artículo $4^{\circ}$. El que coloque petardos u otros objetos similares, sobre los rieles del ferrocarril o de tranvía, incurrirá en multa de dos pesos (\$2) a diez pesos (\$10).

Artículo $5^{\circ}$. El conductor de vehículo que llame a las puertas de las casas, por medio de bocina de automóvil a cualquier hora del día o de la noche, incurrirá en multa de cinco pesos (\$5) a veinte pesos (\$20). (Registro Municipal de Bogotá, 1949, Acuerdo número 85 , p. 296)

En algunos casos los comportamientos de la ciudadanía iban en contravía de las disposiciones de las autoridades. El peatón se acostumbró a que el uso de la bocina era un modo idóneo para que el conductor anunciara su presencia, de suerte que algunos conductores afirmaban que "los peatones ven venir el automóvil y se niegan a ceder el paso y además, se encara con el conductor para decirle: -¿Y eso qué? ¿Qué se hizo el pito? ¿Lo vendió o qué es la cosa?" (Cromos, 1948, p. 21).

En medio del caos y de la imperativa necesidad de disminuir el número de muertos y de heridos por causa de accidentes, entidades particulares como clubes se unían a las autoridades en la realización de campañas de este tipo. Como el caso del Club Los Leones cuyos miembros en 1953 afirmaban que "en la mayoría de los accidentes que se registran en Bogotá los peatones tienen la culpa" (“Un día de cooperación...", 1953, p. 30) y que, por tanto, 
era perentorio buscar alternativas de instrucción para los ciudadanos que no tenían auto.

Las empresas privadas a través de campañas publicitarias también se unieron al objetivo global de disminuir los índices de accidentalidad. Muestra de ello es la extensa campaña adelantada por la compañía Esso de Colombia, y llevada a cabo en periódicos y revistas con el título "Carta abierta de una madre a un conductor". En esta carta se esbozan algunas recomendaciones para que los conductores de toda clase de vehículos tengan en cuenta a los niños en el momento de conducir (Lecturas dominicales, 1950, p. 19).

La difícil situación se agravaba por la ocurrencia de daños colaterales derivados del aumento acelerado de vehículos, como, por ejemplo, la destrucción de vías y la afectación de viviendas por causa del peso de los buses que ahora circulaban por la ciudad ("Non tembles...", 1949, p. 14) o la salida de circulación de los buses a gasolina de la empresa municipal, que generó un caos enorme en la ciudad debido a la disminución de vehículos producto de una avería mecánica de los mismos, a pesar de haber sido puestos en servicio muy pocos años antes. El daño, según se conoció, se debió a que "en un alarde de técnica criolla les quitaron a los buses la primera velocidad para que arrancando en segunda ahorraran combustible" (“De la mula...", 1953, p. 6).

Otros aspectos igualmente críticos fueron el incremento del robo de autos. En 1954, "según estadísticas más o menos veraces, diariamente se roban en Bogotá, por lo menos, un automóvil" "Hurto de carros...", 1954, p. 33), lo que implicaba no solo el robo del auto completo, sino de parte de los automóviles que posteriormente eran comercializadas ("La rueda del delito...", 1950, p. 10). Así mismo la invasión del espacio público era un inconveniente inédito en la ciudad que implicaba profundos problemas, pues "[los autos] [o]cupan permanentemente todos los sitios posibles en las calles, avenidas y parques" (“Ciudad de conquista", 1949, p. 12). Esta situación promovió la puesta en uso de los "estacionómetros", cuyo pago por dos horas era de 60 centavos ("Peros y señales", 1954, p. 11), pero la 
ciudadanía pronto se encontró inconforme debido a que se "tragaba una moneda tras otra sin marcar el tiempo correspondiente (por lo cual los llaman robómetros) y están colocados en sitios donde el estacionamiento entorpece el tránsito" ("La excepción”, 1955, p. 9).

La revista Proa señalaba que era evidente lo "congestionadas y tumultuosas que resultaban las calles de la ciudad debido a las crecientes necesidades de circulación" ("Las calles...", 1950, p. 7), y que por esa razón no debía escatimarse en ideas para aliviar un poco la congestión; se propone, por ejemplo, una restricción vehicular: "la fórmula que se emplearía consistiría en fijar tres días a la semana para que circulen los carros que tengan placa terminada en par y otros tres días para los de placa que finalice en impar" ("El Tráfico", 1953, p. 38). En el mismo sentido, se propuso el uso de las bicicletas. Para tal efecto, se permitió la importación de "veinte mil bicicletas con el objeto de descongestionar el movimiento de pasajeros" (“30 000 vehículos...", 1951, p. 3), aunque la propuesta no llegó a tener la acogida que se esperaba y el uso de las bicicletas de los bogotanos se vio relegado a los domingos y días festivos.

\section{Consideración final}

La situación era caótica y, en muchos casos, desalentadora; parecía ya que ninguna medida podría corregir el difícil tráfico capitalino. La modernización del sistema municipal de transportes, si bien en principio fue gratamente recibida y en sus primeros años de circulación fue elogiada constantemente en páginas de periódicos y revistas interesadas en el tema, poco después comienza a ser blanco de las mismas críticas que tenían que soportar las empresas privadas del transporte privado.

Desde luego que se adelantaban muchas obras: la señalización de las vías y las aceras correspondía a normas internacionales; se trazaban planes de rutas para los buses; se estudiaba la instalación de nuevos semáforos; el municipio importaba más buses; las 
empresas de obras públicas no daban abasto con el trabajo de abrir nuevas vías; el personal de motoristas y policías de circulación se aumentaba, y cada vez eran mejor dotados con motocicletas nuevas y modernas herramientas. Pero esto no fue suficiente para minar el pesimismo que comenzó a apoderarse de muchas personas que veían agotados ya todos los recursos para disminuir los accidentes, ampliar la cobertura del servicio público y promover la descongestión del tráfico.

Con respecto a todas estas medidas, en un diario capitalino algún periodista se preguntaba: “¿se logrará cambiar el panorama actual?”, y él mismo se respondía:

Dificilmente, porque si es verdad que las vías tienden a alargarse y ampliarse de acuerdo con los nuevos programas viales urbanos, también lo es que siguen llegando más automóviles, y más buses y más bicicletas y más camiones. Y el problema, como un gran círculo vicioso, continuará per secula seculorum. Por esto mismo hoy, lo mismo que mañana e igual que siempre resulta mejor andar a pie. (“30 000 vehículos...”, 1951, p. 3)

Cabe tener en cuenta, sin embargo, que aunque las piernas llevasen al que optara por utilizarlas a cualquier lugar y facilitara todos los caminos, podía ocurrir que el impetu las hiciera desaparecer bajo las ruedas inexorables del progreso.

Una revisión a la dinámica constructiva en la ciudad y la especial atención que mereció la infraestructura vial, a los cambios en el transporte urbano colectivo y a la preponderancia del automóvil privado en el sistema de circulación de la ciudad, revela la enorme confusión que hubo entre los habitantes, pero también en los administradores bogotanos durante este periodo. Al principio se consideró que el problema tenía sus raíces en la ausencia de normas sociales, pero pronto se comprobó que los problemas tenían que ver con la generalización de un cierto tipo de vida urbana, más caótica, más acelerada y demandante de una mayor sincronización, que necesitaba de otras medidas para ser controlada. 
Derivado de esto, quizá uno de los impactos más contundentes fue la finalización de una forma de asumir el espacio público y de un modo particular de habitar la ciudad en la que el peatón tenía prelación; se transitaba entonces a una nueva organización citadina en la que los medios motorizados, y especialmente el automóvil, se convertían en el elemento fundamental de la movilidad urbana, probablemente con la vana esperanza de alcanzar la elusiva imagen de una ciudad pujante, tecnificada y capitalista. El anhelo muy pronto se vio frustrado, la movilidad se convirtió en un asunto de salud pública y la Bogotá de los siguientes cincuenta años debió afrontar las consecuencias de las creencias y las decisiones que fueron tan populares a mediados del siglo XX.

\section{Referencias}

30000 vehículos por sólo doce vías arterias circulan hoy en la ciudad. (1951, marzo 1). El Tiempo, p. 3.

Abello, L. (1940, noviembre 23). A través de un tranvía en Bogotá. Estampa: revista semanal de actualidad gráfica, pp. 40-41.

Acosta, J. y Baquero, J. (2005). El tranvía eléctrico de Bogotá y su sistema de movilidad (Tesis de grado para optar al título de Licenciado en Ciencias Sociales). Universidad Distrital Francisco José de Caldas, Bogotá.

Alcalde ordena que no haya tránsito de vehículos por la $7^{\mathrm{a}}$. (1948, octubre 27). El Espectador, pp. 1 y 4.

Algo sobre el tranvía. Colombianos valientes lucharemos. (1944, julio $1^{\circ}$ ). Sábado, p. 12.

Anales del Concejo de Bogotá, N. ${ }^{\circ}$ 1785, Acuerdo N. ${ }^{\circ} 59$ de 1949, s.p.

Andrade, J. (1947, diciembre). Los problemas del tránsito. Santa Fe y Bogotá, Órgano de la Sociedad de Mejoras y Ornato, (17), 76-77. 
Anuario Municipal de Estadística. (1939-1955). Bogotá: s.e.

Aprile, J. (1983). El impacto del 9 de abril sobre el centro de Bogotá. Bogotá: Centro Jorge Eliécer Gaitán.

Arango, S. (1979). Evolución del espacio urbano en Bogotá en el siglo XX (Tesis para optar al Doctorado de 3er. Ciclo). Instituto de Urbanismo de París, Universidad de París XII, Val-de-Marne.

Baquero, J. (2009). Tranvía municipal de Bogotá. Desarrollo y transición al sistema de buses municipal, 1884-1951 (Tesis para optar al título de Magister en Historia). Universidad Nacional de Colombia, Bogotá.

Benevolo, L. (1992). Orígenes del urbanismo moderno. Madrid: Ediciones Celeste.

Benitez, L. (1997). El tranvía símbolo de una Bogotá olvidada: significación del tranvía dentro de la construcción de imaginarios en Bogotá (Tesis de grado para optar al título de Trabajadora Social). Universidad Nacional de Colombia, Bogotá.

Bienes ocultos. (1948, octubre 9). Semana, p. 12.

Carnes, R. (1941, febrero 15). Lo que dicen y lo que vemos en la capital. Estampa. Revista semanal de actualidad gráfica, pp. 17 y 38.

Castañeda, W. (1997). Transporte público, regulación y Estado en Bogotá, 18821980. Bogotá, documento inédito.

Castro-Gómez, S. (2009). Tejidos oníricos. Movilidad, capitalismo y biopolitica en Bogotá. Bogotá: Editorial Pontificia Universidad Javeriana.

Cinco preguntas al señor gerente del tranvía municipal de Bogotá. (1946, enerofebrero). Santa Fe y Bogotá. Órgano de la Sociedad de Mejoras y Ornato, (6-7), 28.

Ciudad arrasada (1947, junio 28), Semana, p. 4

Ciudad de conquista. (1949, septiembre 3). Semana, p. 12. 
Contreras, L. y Restrepo, M. (1985). Historia del tranvía (trabajo de grado para optar al título de Licenciatura en Ciencias Sociales). Universidad Nacional de Colombia, Bogotá.

Cortesía sin frenos. (1949, agosto 20). Semana, p. 14.

Cromos. (1948, junio 5), p. 21.

Cuáles serán las obras para la Conferencia Panamericana. (1946, enero 30). El Tiempo, p. 13.

De la mula al Mack. (1953, mayo 2). Semana, p. 6.

Defensa de los “Zorreros". (1949, agosto 26). El Espectador, p. 4.

Descanso. (1951, julio 7). Semana, p. 7.

El tráfico. (1953, octubre 31). Estampa: revista semanal de actualidad gráfica, pp. 38-39.

El tránsito un problema incipiente de Bogotá. (1939, enero 21). Estampa: revista semanal de actualidad gráfica, pp. 28-29.

En tranvía al pasado. (1948, octubre 30). Semana, p. 10.

Guía de caminantes. (1949, agosto 13). Semana, p. 12.

Ha muerto el tranvía, viva el bus. (1951, julio 2). El Tiempo, p. 7.

Hurto de carros. Droga heroica. (1954, enero 25). Semana, p. 33.

Ibero, M. (1945, marzo 10). Viajando en tranvía. Sábado, p. 13.

Jaramillo S. y Parias A. (1995). Vida, pasión y muerte del tranvía en Bogotá. Bogotá: Universidad de los Andes - Documentos del CEDEC.

La Circulación el Gran Problema de Bogotá. (1946). Cromos. 
La Excepción. (1955, febrero 4). Semana, p. 9.

La rueda del delito. (1950, octubre 14). Semana, p. 10.

La semana de la cortesía. (1939, febrero 25). Estampa: revista semanal de actualidad gráfica, p. 28.

Las calles bogotanas. (1950, diciembre). Proa, p. 7.

Lecturas dominicales. (1950, octubre). El Espectador, p. 19.

Lezama. J. L. (2005). Teoría social, espacio y ciudad. México D.F.: Editorial E1 Colegio de México.

Los buses-trolley en la Avenida Caracas. (1948, octubre 6). El Espectador, p. 3.

Los transportes urbanos en Bogotá. (1949, abril). Proa, p. 34.

Lucha por la vida. (1949, febrero 5). Semana, p. 11.

Marinetti, T. (1909, febrero 20). Primer Manifiesto Futurista. Recuperado de https://goo.gl/PIfO41

Mazuera, F. (1972). Cuento mi vida. Bogotá: Sin Editorial.

Montezuma, R. (2000). Presente y futuro de la movilidad urbana en Bogotá, retos y realidades. Bogotá: Veeduría Distrital - Centro Editorial Javeriano (CEJA).

Moreno, J. (1941, julio 12). Progresos y deficiencias de la circulación. Estampa: revista semanal de actualidad gráfica, p. 22.

Noguera, C. (2000). La construcción de la ciudad moderna. Urbanismo y urbanidad. En C. Noguera, A. Álvarez y J. Castro (Eds.), La ciudad como espacio educativo. Bogotá y Medellín en la primera mitad del siglo XX. Bogotá: Arango Editores.

"Non tembles terra". (1949, julio 23). Semana, p. 14. 
Para la Panamericana. (1947, septiembre 7). Semana, p. 18.

Pardo, C. (1949, agosto 5). La ciudad antigua y la ciudad vieja. El Espectador, p. 4.

Park, R. (1925). La ciudad. Sugerencias para la investigación de la conducta humana en un ambiente urbano (Trad. A. Henao Valencia). Versión inédita. Recuperado de http://www.pedagogica.edu.co/storage/rce/articulos/rce3637_08tex.pdf

Peros y señales. (1954, junio 28). Semana, p. 11.

Registro Municipal de Bogotá. (1949). Acuerdo número 85, p. 296.

Reglamento del Departamento de Tráfico. Tranvía Municipal de Bogotá. (1941). Bogotá: Tipografia Prag.

Ritter, H. (1946, agosto). La Avenida de las Américas. Proa, (1), 30-33.

Rodríguez, L. (2003). El tranvía municipal de Bogotá, 1910-1954. En L. Rodríguez y S. Núñez (Eds.), Empresas públicas de transporte en Bogotá. Siglo XX. Bogotá: Alcaldía Mayor.

Saldarriaga, A. (2000). Bogotá Siglo XX. Urbanismo, arquitectura y cultura urbana. Bogotá: Alcaldía Mayor.

Sanz de Santamaría, C. (1944, marzo 31). Transportes urbanos, energía eléctrica, teléfonos. Registro Municipal.

Se pide impuesto para las tertulias callejeras. (1949, julio 7). Revista Santa Fe y Bogotá. Órgano de la Sociedad de Mejoras y Ornato, p. 9.

Simmel, G. (1986, ene-mar). Las grandes urbes y la vida del espíritu. Cuadernos Politicos, (45), 5-10.

Sólo en tranvías abiertos pueden viajar las niñas de colegio. (1949, julio 9). El Tiempo, p. 3. 
Suprimidos los últimos tranvías que estaban prestando servicio. (1951, julio $\left.1^{\circ}\right)$. El Tiempo, p. 1 .

Téllez, H. (1978). 1948. En Bogotá reseñada por cronistas y viajeros ilustres (pp. 164-168). Bogotá: Ed. Escala.

Un día de cooperación cívica. (1953, agosto 15). Revista Ya, p. 30.

Uribe, S. (1947). Problemas del tránsito urbano. Registro Municipal. Bogotá: Imprenta Municipal.

Urry, J. (2004). The 'system' of Automobility. Theory, culture and society, $21(4 / 5), 2539$.

Vega-Centeno, P. (2003). Movilidad (espacial) y vida cotidiana en contextos de metropolización. Reflexiones para comprender el fenómeno urbano contemporáneo. Debates sociología, (28), 19-51.

Villegas, B. (1995). Carros. El automóvil en Colombia. Bogotá: Villegas Editores.

¿Y sus modales ¡Qué tal!? (1940, diciembre 7). Estampa. Revista semanal de actualidad gráfica, p. 14.

Zambrano, F. (2007). Historia de Bogotá Siglo XX. Bogotá: Villegas Editores.

\section{Cómo citar este artículo}

Prieto Páez, L. (2018). Entre rieles y asfalto. Bogotá, transporte y vida urbana: 1938-1954. Universitas Humanística, 85, 59-100. https://doi.org/10.11144/ Javeriana.uh85.rabt 